\title{
Studies on Density, Percentage Composition and Seasonal Variations of Phytoplankton in a Perennial Pond Ecosystem of Tripura, India with a note on Physico-chemical Factors
}

\author{
Saumen Chakrabarti* \\ Department of Zoology, Women's College, Agartala, Tripura, India \\ *Corresponding author
}

\section{Keywords}

Phytoplankton density, Percentage composition, Seasonal variations, Physico-chemical factors, Pond ecosystem

Article Info

\section{Accepted:}

20 June 2021

Available Online: 10 July 2021
The present study makes a record on the density and seasonal variations of phytoplankton in a perennial pond ecosystem of Tripura during a period from March 2019 to February 2021. The present observation recorded the presence of 14 species of phytoplankton in the studied perennial pond. The percentage composition of different families under which different phytoplankton species belongs was noted as well as percentage composition of each phytoplankton species was also noted. Amongst the density of the phytoplanktonic groups, the density of the Chlorophyceae was highest in winter (1153 ind/l) and lowest in monsoon (379 ind/l), density of the Cyanophyceae was found to highest in monsoon (613 ind/l) and lowest in summer (139 ind/l) while the density of the Bacillariophyceae was highest in winter (317 ind/l) and lowest in monsoon season (63 ind/l), Euglenophyceae showed its highest density during winter (67 ind/l) and lowest density (11 ind/l) in the monsoon. Notable physico-chemical factors of the studied pond were also noted during the occurrence of phytoplankton. The present study infers that densities of different phytoplankton groups may vary with different seasons of the year due to dynamic nature of the aquatic ecosystem and might be also due to optimal condition in the physico-chemical parameters of the studied lentic ecosystem.

\section{Introduction}

Phytoplankton are small to microscopic, freefloating algae that inhabit the open water of all aquatic and semi-aquatic biotopes (Reynolds, 2006). Phytoplankton are highly diverse group of photoautotrophic organisms having chlorophyll- a and unicellular reproductive structures which lie in the base of aquatic food webs and play crucial role to maintain productivity of any aquatic ecosystems(Yerli et al., 2012). The species composition, period of occurrence and density of phytoplankton are of fundamental importance (Singh and Swaroop, 1979; Gehlot and Barupal, 2010). As the phytoplankton plays an important role in oxygen amelioration, binding and removal of certain toxic substances from the water 
body, so the study of phytoplankton is of immense limnological importance (Sen et al., 2013; Gupta et al., 2015). Phytoplankton account for approximately $50 \%$ of the photosynthesis on this planet, over $99.9 \%$ of all the carbon dioxide that has been incorporated into living things over geologic time is buried in marine sediments thereby indicating that phytoplankton play very crucial role in regulating the amount of carbon in the atmosphere (Peter et al., 2002). Phytoplankton is known to exhibit distinct seasonal succession with the cyclic changes of environmental factors in any water bodies (Kopoczynska, 1980). In aquatic ecosystem, the availability of nutrients, light, grazing, water mixing regimes, basin morphometry etc., are of great impact on the seasonal variations of phytoplankton (Kagami et al., 2006). Phytoplankton evaluates the water quality through changes in its species composition, distribution and proportion of sensitive species (Indabawa, 2010). Phytoplanktons which inhabit the euphotic zone are the main causes of high turbidity in water if density increases (Verma and Mohanthy, 1995). Phytoplankton provides live food for all other aquatic organisms ranging from benthic invertebrates to fish (Sarvala et al., 1998). The magnitude and dynamics of phytoplankton are increasingly considered as bio indicators to assess the trophic status of an aquatic ecosystem and helps in assessing the extent of eutrophication (Galijuri et al., 2002; Shashi Shekhar, 2008). Phytoplankton communities commonly consist of assemblages of four major taxonomic groups viz., Chlorophyceae, Cyanophyceae, Bacillariophyceae and Euglenophyceae. Different groups of phytoplankton require different range of water quality factors (such as temperature, $\mathrm{pH}$, dissolved oxygen) and they are seen to be present only when the suitable ranges of these water quality parameters are available in a water body (Willén, 2001). Certain unfavourable alteration in the water quality parameters could adversely affect phytoplankton yield, i.e. primary productivity which in turn brings about attendant problems(such as depletion of dissolved oxygen concentrations at night or super saturation of dissolved oxygen in the day, shortage of food, competition for available food, stress and death) to all aquatic consumer life(Grover, 1990; Sarnelle,1992). Ponds are rich components of biodiversity like flora, fauna of natural, local and regional significance (Jeffries, 2005). Ponds habitats are also very vulnerable especially to pollution stresses because their small size gives them limited buffering capacity compared to lakes and rivers (Scheffer et al., 2006). In the present study, an attempt was undertaken to observe the density, percentage composition and seasonal variations of phytoplankton in a perennial pond ecosystem of Tripura, India.

\section{Materials and Methods}

The present observation was carried out in a freshwater pond located at Shibnagar, Agartala, Sadar Subdivision, West District of Tripura, India during March 2019 to February 2021. It lies geographically at the Latitude $23^{\circ}$ $50^{\prime} 9.78^{\prime \prime} \mathrm{N}$ and Longitude $91^{\circ} 16^{\prime} 45.80^{\prime \prime} \mathrm{E}$. The studied pond is perennial and almost rectangular shaped. The surface area of the water body is of about 0.64 ha. The mean depth of the water column in the studied pond fluctuates from $1.0 \mathrm{~m}$ during summer season to $2.5 \mathrm{~m}$ in the monsoon season. The littoral zone of the pond harbours macrovegetations such as Eichhornia crassipes and Salvinia sp. This pond is selected with the objectivity that this pond is used for scientific rearing of Indian Major Carps. The phytoplankton have been collected from the littoral zones of the studied pond through plankton net at weekly intervals and fixed immediately with $4 \%$ formalin and enumeration is being done quantitatively in the laboratory through Sedgwick Rafter Plankton Counting Cell and 
results were expressed as ind/l. Phytoplankton species was identified up to species level following keys (Philipose, 1960; Fritsch, 1979). Physico-chemical parameters such as water temperature, $\mathrm{pH}$, transparency were determined in situ and the other water quality parameters viz., dissolved oxygen, free carbon dioxide, bicarbonate, dissolved organic matter, silicate, phosphate phosphorus and nitrate nitrogen have been analysed in the laboratory following the standard methods(APHA, 2012).

\section{Results and Discussion}

The present observation recorded the presence of 14 species of phytoplankton (Table 1).

Amongst 14 species of phytoplankton, 9 species under the class Chlorophyceae belongs to 9 genera and 6 families; 3 species under the class Cyanophyceae belongs to 3 genera and 3 families; 1 species under the class Bacillariophyceae belongs to 1 genera and 1 family and1 species under the class Euglenophyceae belongs only 1 genera and 1 family. Quantitative analysis during the study period revealed that amongst the Chlorophyceae, Scenedesmaceae is the dominant family with 3 species (Scenedesmus quadricauda, Coelastrum microporum and Tetrastrum punctatum) followed by Selenastraceae with 2 species(Monoraphidium arcuatum and Ankistrodesmus spiralis), Zygnemataceae with 1 species (Spirogyra parvula), Desmidiaceae with 1 species (Cosmarium nitidulum), Chlorellaceae with 1 species (Chlorella vulgaris) and Hydrodictyaceae with 1 species (Pediastrum tetras). Amongst Cyanophyceae, Merismopedia minima belongs to family Merismopediaceae, Anabaenopsis raciborskii belongs to family Nostocaceae and Chroococcus dispersus belongs to family Chroococcaceae. Amongst Bacillariophyceae phytoplankton, Pinnularia virdis belongs to family Pinnulariaceae. Euglena acus was the only species belongs under the class Euglenophyceae.

The percentage composition of different families under which different phytoplankton species exist was also noted (Fig.1). Amongst Chlorophyceae, the percentage composition of family Scenedesmaceae, Selenastraceae, Zygnemataceae, Desmidiaceae, Chlorellaceae and Hydrodictyaceae were $35 \%, 19 \%, 6 \%$, $3 \%, 9 \%$ and $4 \%$ respectively. Amongst Cyanophyceae, the percentage composition of family Merismopediaceae, Nostocaceae and Chroococcaceae. were $11 \%, 6 \%$ and $2 \%$ respectively. In the Bacillariophyceae phytoplankton, the percentage composition of family Pinnulariaceae was $3 \%$ while in the Euglenophyceae phytoplankton, the percentage composition of the family Euglenaceae was 2\% (Fig.1).

The percentage composition of each phytoplankton species in the studied pond was also noted (Fig.2). Amongst Chlorophyceae phytoplankton, the percentage composition of the Scenedesmus quadricauda, Coelastrum microporum and Tetrastrum punctatum under the family Scenedesmaceae were $21 \%, 9 \%$ and 5\% respectively. The percentage composition of the Monoraphidium arcuatum and Ankistrodesmus spiralis under the family Selenastraceae were $13 \%$ and $6 \%$. The percentage composition of the Spirogyra parvula under the family Zygnemataceae was $6 \%$, Cosmarium nitidulum under the family Desmidiaceae was 3\%, Chlorella vulgaris under the family Chlorellaceae was $9 \%$ and Pediastrum tetras under the family Hydrodictyaceae was 4\%, Amongst Cyanophyceae phytoplankton, the percentage composition of Merismopedia minima belongs to family Merismopediaceae was $11 \%$, Anabaenopsis raciborskii belongs under family Nostocaceae was 6\% and Chroococcus dispersus belongs under family Chroococcaceae was $2 \%$. Amongst, 
Bacillariophyceae phytoplankton, the percentage composition of Pinnularia virdis belongs under the family Pinnulariaceae was 3\%. In the Euglenophyceae phytoplankton, the percentage composition of Euglena acus under the family Euglenaceae was 2\% (Fig.2).

Amongst the density of the phytoplanktonic groups, the density of the Chlorophyceae was highest in winter (1153 ind/l) and lowest in monsoon season (379 ind/l) during two years study period from March 2019 to February 2021. The density of the Cyanophyceae was found to highest in monsoon season (613 ind/l) and lowest during summer season (139 ind/l) during two years study period. The density of the Bacillariophyceae was highest in winter (317 ind/l) and lowest in monsoon season $(63 \mathrm{ind} / \mathrm{l})$. Euglenophyceae was the least dominant group of phytoplankton and its highest density was recorded in winter (67 ind/l) and lowest density (11ind/l) in monsoon (Fig3).

The chlorophyceae showed higher density in winter coinciding with low temperature and high dissolved oxygen (Venkateshwarlu, 1969; Verma and Mohanty, 1995). On the contrary, cyanophyceae showed highest density in monsoon and this may be attributed to moderate temperature, and higher concentration of nutrients such as phosphate, calcium and magnesium during monsoon favours the luxuriant growth of the cyanophyceae (Kavitha and Balasingh, 2007). Bacillariophyceae showed highest density during winter, which may be due to low temperature, higher range of nitrate nitrogen and lower levels of phosphate (Tilman et al., 1986; Bhat et al., 2012). The density of chlorophyceae, bacillariophyceae and euglenophyceae showed lowest density during monsoon season. Rana (1991) and Jadhav and Chavan (2009) reported that during monsoon season, high rainfall causes flooding of water bodies which in turn causes drifting of phytoplankton along with the water and as a result lowest density of phytoplankton was observed in the monsoon season. Pundhir and Rana (2002) opined that during monsoon, turbidity of the water becomes high and this high turbidity level have an adverse effect on the abundance of phytoplankton by absorbing solar energy in the surface water thereby impairing the photosynthesis process which in turn causes a sharp fall in the phytoplankton density during monsoon.

Physico-chemical parameters of the studied pond water were noted (Table.2).

All four groups of phytoplankton recorded in the studied pond showed their peak abundance during summer season. Researchers (Ganapati and Raman, 1979; Nazneen, 1980) opined that long duration of photoperiod coupled with high temperature favoured the growth of phytoplankton during summer season. In the present observation, the highest density of phytoplankton was recorded in the temperature range of $24-28^{\circ} \mathrm{C}$. Nandan and Patel (1992) reported that high $\mathrm{pH}$ values promote the algal growth. In the present observation, the highest density of phytoplankton was recorded in the $\mathrm{pH}$ value of 7.4-7.6). Asha (2015) observed negative correlation between phytoplankton abundance and $\mathrm{pH}$ and reported that acidic water resulted in low phytoplankton density. Hulyal and Kaliwal (2009) reported that the elevated level of nitrate nitrogen and $\mathrm{pH}$ favours the proliferation of cyanophyceae in lentic ecosystem. In the present observation, density of the members of cyanophyceae was recorded in the nitrate nitrogen value of $0.07-0.08 \mathrm{ppm}$.

The dominancy of bacillariophyceae correlated with high concentration of silicate (Mohamed and Nablia, 2006). In the present study, highest density of the members of bacillariophyceae was observed silicate concentration of 11.2-12.6 ppm. 
Table.1 List of Phytoplankton species in the studied pond

\begin{tabular}{|l|l|l|}
\hline 1.Scenedesmus quadricauda & 7.Cosmarium nitidulum & 13. Pinnularia virdis \\
\hline 2. Coelastrum microporum & 8.Chlorella vulgaris & 14. Euglena acus \\
\hline 3.Tetrastrum punctatum & 9. Pediastrum tetras & \\
\hline 4. Monoraphidium arcuatum & 10. Merismopedia minima & \\
\hline 5. Ankistrodesmus spiralis & 11. Anabaenopsis raciborskii & \\
\hline 6.Spirogyra parvula & 12. Chroococcus dispersus & \\
\hline
\end{tabular}

Table.2 Physico-chemical parameters of the studied pond

\begin{tabular}{|l|c|c|}
\hline \multicolumn{1}{|c|}{ Physico-chemical factors } & Range & Mean \\
\hline Water temperature $\left({ }^{\circ} \mathbf{C}\right)$ & $10-36$ & 28 \\
Transparency $(\mathbf{c m})$ & $8-20$ & 11.6 \\
pH & $6.4-8.6$ & 7.4 \\
Dissolved oxygen(ppm) & $5.2-7.6$ & 5.8 \\
Free carbon dioxide(ppm) & $1.2-2.8$ & 1.4 \\
Bicarbonate alkalinity(ppm) & $86-132$ & 110 \\
Dissolved organic matter(ppm) & $11.4-18.6$ & 12.2 \\
Silicate(ppm) & $7.2-14.4$ & 9.4 \\
Phosphate phosphorus(ppm) & $0.01-0.2$ & 0.09 \\
Nitrate nitrogen(ppm) & $0.01-0.2$ & 0.07 \\
\hline
\end{tabular}

Fig.1 Percentage composition of different families of phytoplankton in the studied pond

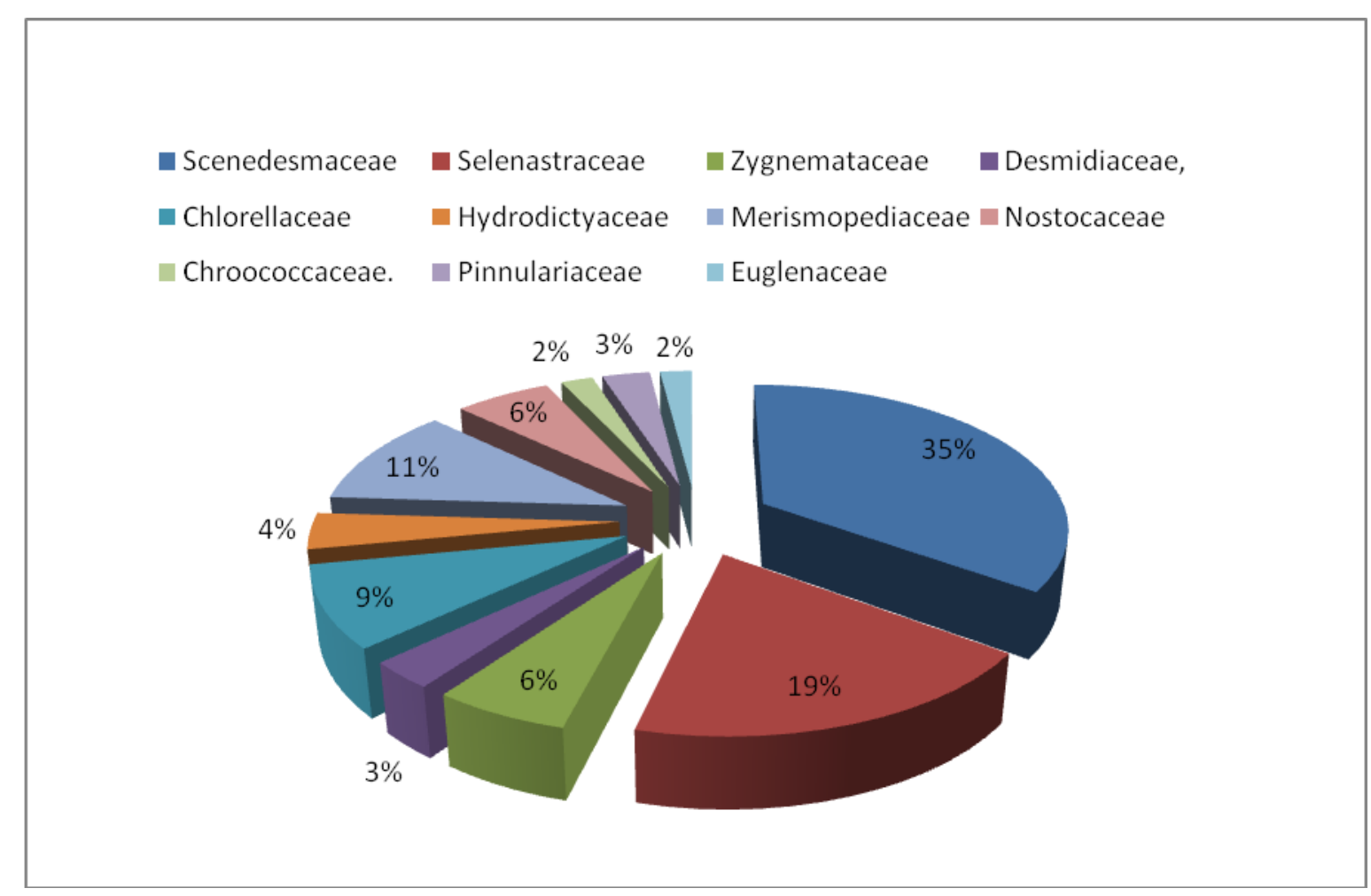


Fig.2 Percentage composition of each phytoplankton species of the total phytoplankton population in the studied pond

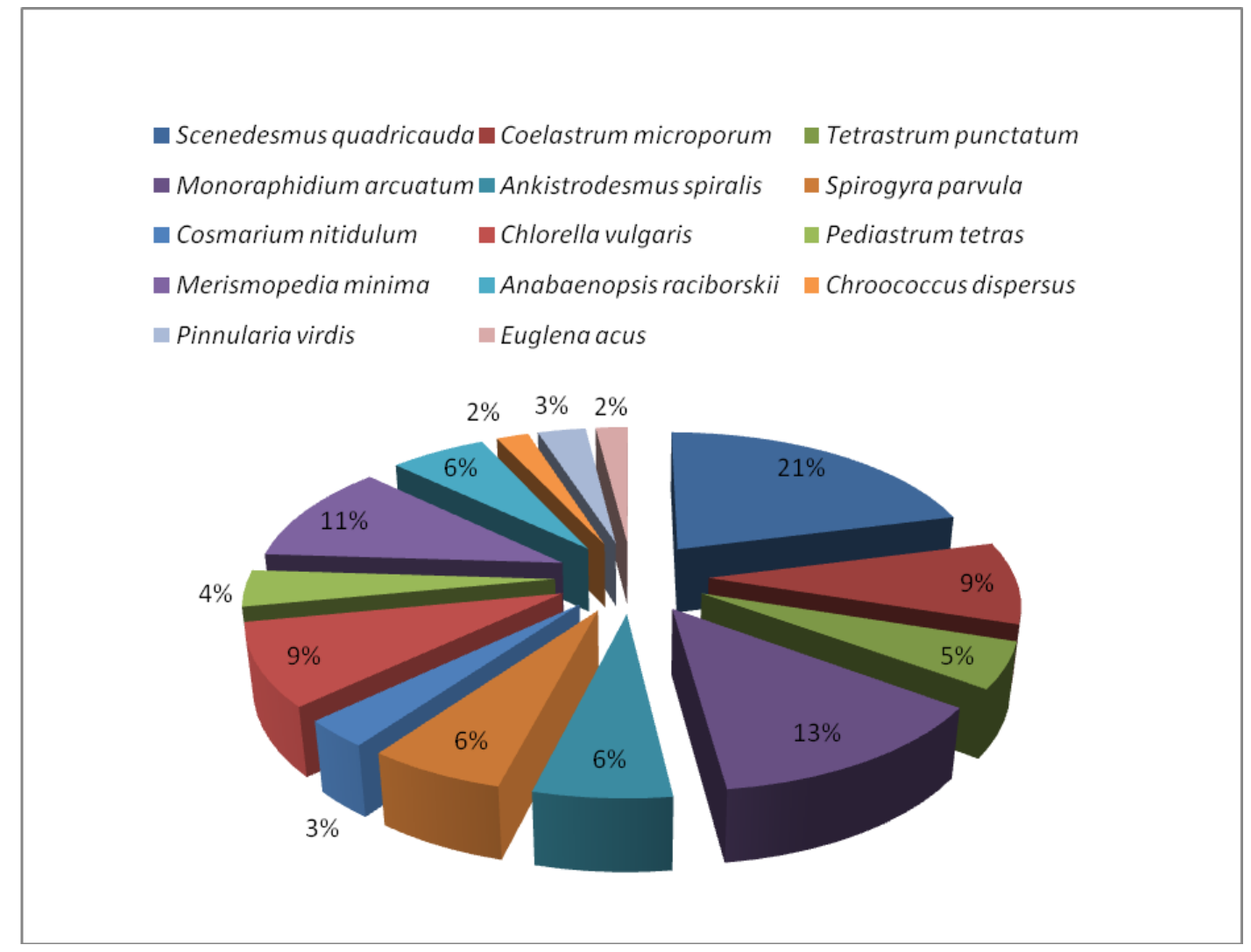

Fig.3 Seasonal variations in the mean density (ind/l) of different groups of phytoplankton

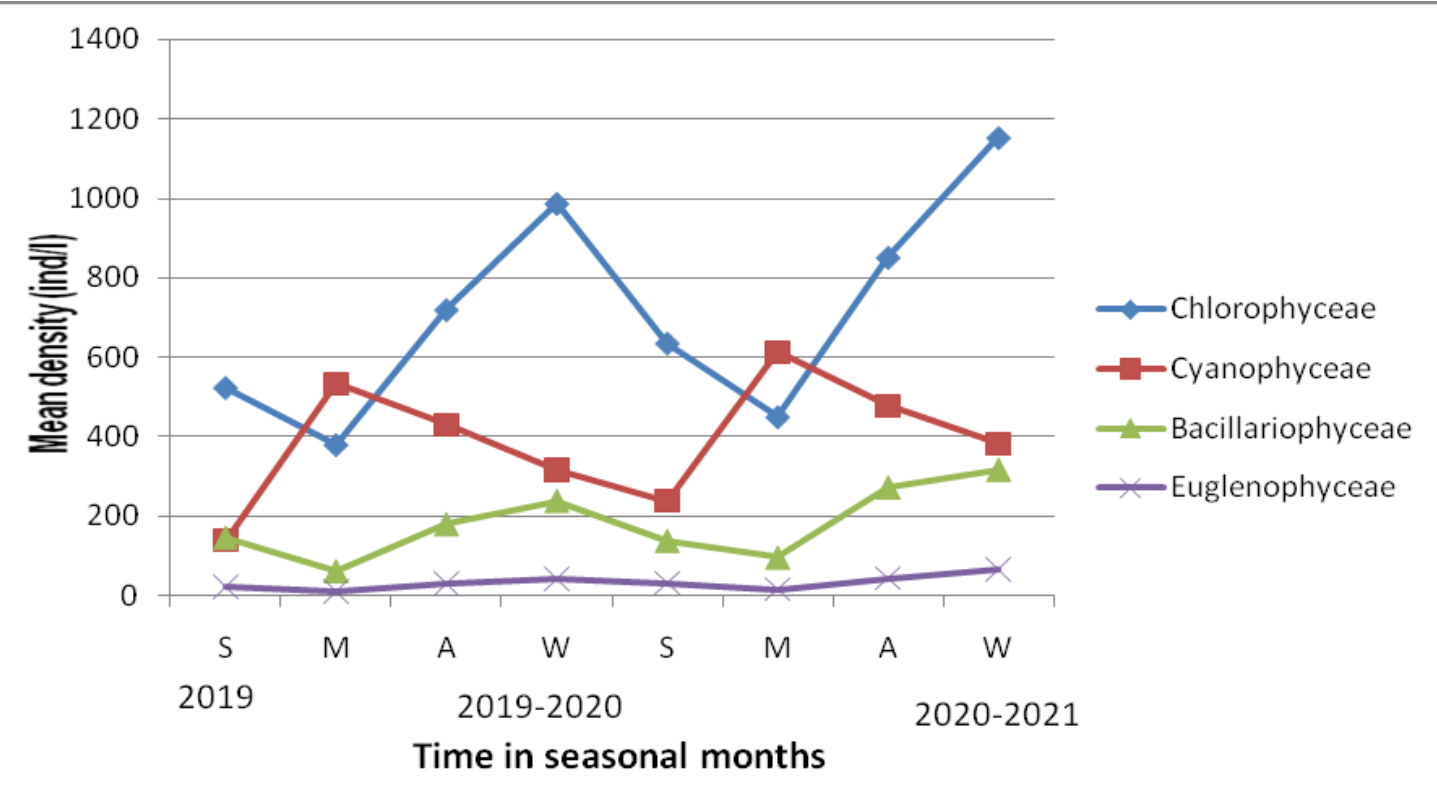

Abbreviations used: $\mathrm{S}=$ Summer (March to May); $\mathrm{M}=$ Monsoon (June to August); A=Autumn (September to October); W=Winter (November to February) 
The present study infers that different groups of phytoplankton although have different species composition and environmental requirements, yet they thrive successfully and co-exist in the same water body and their densities vary with different seasons of the year due to dynamic nature of the aquatic ecosystem and might be also due to optimal condition in the physico-chemical parameters of the studied lentic ecosystem.

The ecological niches in an aquatic ecosystem are very plastic and are likely to be oscillate widely which in-turn influence in the composition and abundance of phytoplankton. A particular population of phytoplankton is able to exploit its ecological niches to its maximum and the peaks of phytoplankton are, therefore due to differential ecological niches of studied lentic ecosystem. So, in the light of present study, it can be concluded that not a single factor but multiple factors governs over the densities and seasonal variations of phytoplankton in the studied pond ecosystem.

\section{Acknowledgements}

The author also expresses his deepest sense of gratitude and obligation to the Principal, Women's College, Agartala, Tripura for providing laboratory facility.

\section{References}

APHA, 2012. Standard Methods for the Examination of Water and Wastewater. 22nd ed. APHAAWWA- WEF, Washington, DC.

Asha, M. S. 2015. Effect of Water Quality on Phytoplankton Abundance in Selected Ponds of Nedumangad Block Panchayat, Kerala. Emer. Life Sci. Res.1 (2):35-40.

Bhat, N. A., Wanganeo, A., Raina, R., Dar, J.A. and Naik, A. A. 2012. Phytoplankton diversity in relation to physico-chemical characteristics of Upper Basin (Bhoj Wetland), Bhopal, India. International Journal of Geology, Earth and Environmental Sciences. 2(3): 147-153.

Fritsch F. E. 1979. The structure and reproduction of the algae. Vol.1. Vikas Publishing House Pvt. Ltd., New Delhi, $791 \mathrm{pp}$.

Galijuri, M. C., Santos, A. C. A. and Jati, S. 2002. Temporal change in the phytoplankton community structure in a tropical and eutrophic reservoirs (Barra Bonita, S.P. Brazil). J. Plank. Res. 24: 617-634.

Ganapati, P. N. and Raman, A. V. 1979. Phytoplankton in relation to pollution in Visakhapatnam harbour, East-Coast of India. Indian Journal of Marine Science. 3: 184.

Gehlot, R. K. and Barupal, G. K. 2010. Seasonal variations in phytoplanktons of Kolayat lake, Bikaner, Rajasthan. Indian J. Environ. \& Ecoplan. 17(1-2): 195-202.

Grover, J. P. 1990. Resource competition in a variable environment: Phytoplankton growing according to Monod's model. Am. Nat. 136: 771-789.

Gupta C, Prakash D, Gupta S. 2015. Role of Blue Green Algae in Environment Management. In: Ram Prasad (Eds.). Environmental Microbiology, I.K. International Publishing House Pvt. Ltd., India.

Hulyal, S. B. and Kaliwal, B. B. 2009. Dynamics of phytoplankton in relation to physico-chemical factors of Almatti reservoir. Environ. Monit. Assess. 153: 45-59.

Indabawa, I. I. 2010. Studies on Limnological parameters and Phytoplankton dynamic of Nguru lake Yobe state Nigeria. Bioscience Resources Communication. 21(4): 57-80.

Jadhav, S. B. and Chavan, N. S. 2009. Study 
of phytoplankton population from water resources of Jotiba (Wadi Ratnagiri), Maharashtra. Nature, Environment and Pollution Technology. 8(1):37-42.

Jeffries, M. 2005. Small ponds and big landscapes: the challenge of invertebrate spatial and temporal dynamics for European pond conservation. Aquatic Conservation: Marine and Freshwater Ecosystems 15: 541-547.

Kagami, M., Gurung, T. B., Yoshida, T., and Urabe, J. 2006. To sink or to be lysed? Contrasting fate of two large phytoplankton species in Lake Biwa. Limnol. Oceanogr. 51: 2775- 2786.

Kavitha, A. and Balasingh, G. S. 2007. Seasonal abundance and phytoplankton diversity of a sacred grove freshwater ecosystem of Kanya Kumari district, south Tamil Nadu. Indian Hydrobiology. 10(2): 231-236.

Kopoczynska E. E. 1980. Seasonal variation in phytoplankton in the grand river mouth area of lake Michigan. Polskie Archiwum Hydrobiologii. 27(1): 95123.

Mohamed, A. O. and Nablia, R. H.2006. Impact of environmental conditions on the phytoplankton structure in the Mediterranean Sea Lagoon, Lake Barullus, Egypt. Water Air SoilPoll.172:129-150.

Nandan, S. N. and Patel, R. J. 1992. Ecological studies of algae In: Aquatic ecology (ed. by Mishra, S. R. and Saksena, D. N.). Ashish Publishing House. New Delhi, pp. 69-99.

Nazneen, S. 1980. Influence of hydrological factors on the seasonal abundance of phytoplankton in Kinjhar Lake, Pakistan. Int. Revue ges. Hydrobiol. 65(2): 269-282.

Peter, J. LeB., Williams, David N. Thomas, Colin and Reynolds, S. 2002.
Phytoplankton Productivity: Carbon Assimilation in Marine and Freshwater Ecology. Wiley-Blackwell, 400pp.

Philipose, M. T. 1960. Freshwater phytoplankton in inland fisheries. Proc. Symp. Algo. ICAR, New Delhi, 272291.

Pundhir, P. and Rana, K. S. 2002. Pollution dynamics of phytoplankton in the wetland area of Keoladeo National Park, Bharapur (Rajsthan). Eco. Env. and Cons. 8(3): 253-235.

Rana K. S. 1991. Impact of solar radiation on the aquatic ecosystem. A case study of Soor Sarowar, Agra. Nature, Environment and Pollution Technology. 8(2): 43-49.

Reynolds, C. S. 2006.The ecology of phytoplankton. Cambridge University Press, UK.

Sarnelle, O. 1992. Nutrient enrichment and grazer effects on phytoplankton in lakes. Ecology. 73: 551-560.

Sarvala, Helminen H., Saarikari, V., Salonen, S. and Vuorio K. 1998. Relations between planktivorous fish abundance, zooplankton and phytoplankton in three lakes of differing productivity. Hydrobiologia. 3 \& 3: 81-95.

Scheffer, M., Geest, G. J. V., Zimmer, K., Jeppesen, E. and Sondergaard, M. 2006. Small habitat size and isolation can promote species richness: Secondorder effects on biodiversity in shallow lakes and ponds. Oikos. 112: 227-231.

Sen B, Alp M. T, Sonmez F, Kocer M. A. T, Canpolat O. 2013. Relationship of Algae to Water Pollution and Waste Water Treatment. In: Elshor-bagy, W. and R.K. Chowdhury (Eds.),. Water Treatment, Intech Open Limited, London.

Shashi Shekhar, T. R., Kiran, B. R., Puttaiah, E. T., Shivraj, Y. and Mahadevan, K. M. 2008. Phytoplankton as index of water quality with reference to 
industrial pollution. J. Environ. Biol., 29(2): 233-236.

Singh, S. R. and Swaroop, K. 1979. Limnological studies of Suraha Lake(Ballia). II. The periodicity of phytoplankton. J. Indian Bot. Soc. 58:319-329.

Tilman, D., Kiesling, R., Strener, R. Kilhom, S. and Johnson, F. 1986. Green, blue green and diatom algae: taxonomic differences in competitive ability for phosphorus, silicon and nitrogen. Arch. Hydrobiology. 106: 473-485.

Venkateshwarlu, V.1969. An ecological study of the algae of the river Moosi, Hyderabad, India with special reference to water pollution. I. Physico-chemical complexes-2. Factors influencing the distribution of algae. Hydrobiol. 33(1): 117-143

Verma, J. and Mohanthy, R. C. 1995. Phytoplankton and its correlation with certain physico-chemical parameters of Dammukundpur pond. Poll. Res. 14: 233-242.

Willén E. 2001. Phytoplankton and Water Quality Characterization: Experiences from the Swedish Large Lakes Mälaren, Hjälmaren, Vättern and Vänern. Ambio. 30(8): 529-537

Yerli S. V, Kivrak E, Gürbüz H, Manav E., Mangit F, Türkecan O. 2012. Phytoplankton community, nutrients and chlorophyll $a$ in Lake Mogan (Turkey), with comparison between current and old data. Turkish Journal of Fisheries and Aquatic Sciences. 12: 95-104.

\section{How to cite this article:}

Saumen Chakrabarti. 2021. Studies on Density, Percentage Composition and Seasonal Variations of Phytoplankton in a Perennial Pond Ecosystem of Tripura, India with a note on Physico-chemical Factors. Int.J.Curr.Microbiol.App.Sci. 10(07): 662-670. doi: https://doi.org/10.20546/ijcmas.2021.1007.072 